\title{
PENAMBANGAN DATA FORMAT TEXT EXCEL DENGAN SOFTWARE TANAGRA
}

\author{
Oleh : \\ Julsam $^{1)}$, Handryawan Adnan Mooduto ${ }^{1)}$, Alexyusandria ${ }^{2)}$ \\ ${ }^{1)}$ Staf pengajar jurusan Elektro Politeknik Negeri Padang \\ ${ }^{2)}$ Staf pengajar Institut Teknologi Padang
}

\begin{abstract}
This article describes about Tanagra software application on data mining. Tanagra is data mining software which can be used to access some existing data mining method. Data is built using excel with text data type. This application use the dataset of women with begnin or malignant. The result inform from 699 sample for Univariate Continuous Statistic have begin $65,52 \%$ and malignant $34,48 \%$. The other information is the begnin has less mitos $(1,6: 1,59)$, the malignant has more ucellshape $(6,56: 3,21)$
\end{abstract}

Keyword: tanagra software, data mining, begnin, malignant

\section{PENDAHULUAN}

Dalam melaksanakan penelitian, peneliti muda ataupun peneliti yang akan melakukan pengolahan data sering terbentur pada proses pengolahan data secara statistik. Banyak software yang dapat digunakan, masing-masing dengan kelebihan dan kekurangannya memberikan kemudahan pada peneliti untuk melaksanakan pengolahan data. Yang terpenting adalah bagaimana melakukan penambangan informasi dari data yang diperoleh (data mining).

Tanagra adalah sebuah software data mining yang dibangun dengan tujuan untuk memberikan akses kepada sejumlah metode data mining yang ada. Tanagra tidak mempersoalkan format bilangan dari file data set yang diimport, dan juga tidak berurusan dengan perbaikan data yang hilang. Dalam tulisan ini akan dijelaskan bagaimana langkah Tanagra dalam mengimport data yang dibangun dalam format spreadsheet
Excel kedalam Tanagra untuk diproses. Dengan Excel pembangunan data dapat dilakukan dengan mudah namun disimpan dengan format text.

\section{Rumusan Masalah}

Dari penjelasan diatas dapat dirumuskan permasalahan sebagai berikut :

1. Bagaimana memanfaatkan software Tanagra dalam penambangan data.

2. Bagaimana memproses data yang dibangun dengan Excel.

\section{Tujuan}

Adapun yang menjadi tujuan dari tulisan ini adalah sebagai berikut :

1. Menjelaskan penggunaan Tanagra dalam penambangan data

2. Menjelaskan kerja Tanagra dalam memproses data yang dibuat dengan Excel 
Membangun Data dengan Excel

Pembangunan data dengan Excel

dilakukan tidak beda dengan mambangun data yang selama ini dilakukan oleh pengguna Excel. Seperti diperlihatkan pada gambar 1. data yang dibangun dalam Excel adalah data tentang cuaca. Setelah data terbentuk langkah berkutnya hádala melakukan penyimpanan data. Penyimpanan data dilakukan seperti halnya menyimpan data Excel lainnya, namun dalam tipe text (Tab delimited) dengan meng-klik File/Save As, selanjutnya set tipe data seperti dicontohkan pada gambar 2 ,

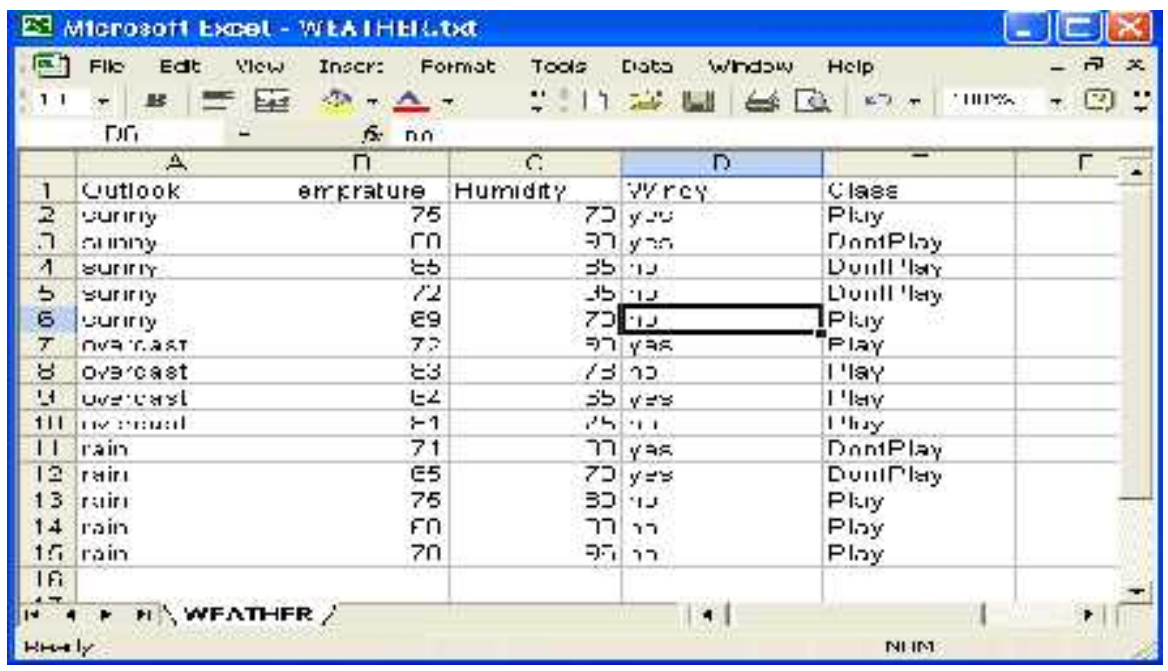

Gambar 1. Contoh Data Dibangun Dengan Excel

Setelah memasukkan nama file (contoh :

Weather) dan memilih tipe filenya, diteruskan dengan mengeksekusinya dengan menekan tombol save, setelah itu data siap untuk di import kedalam Tanagra. File yang dibuat ini dapat dilihat kembali isinya dengan editor lain seperti Windows notepad dan editor lainnya.

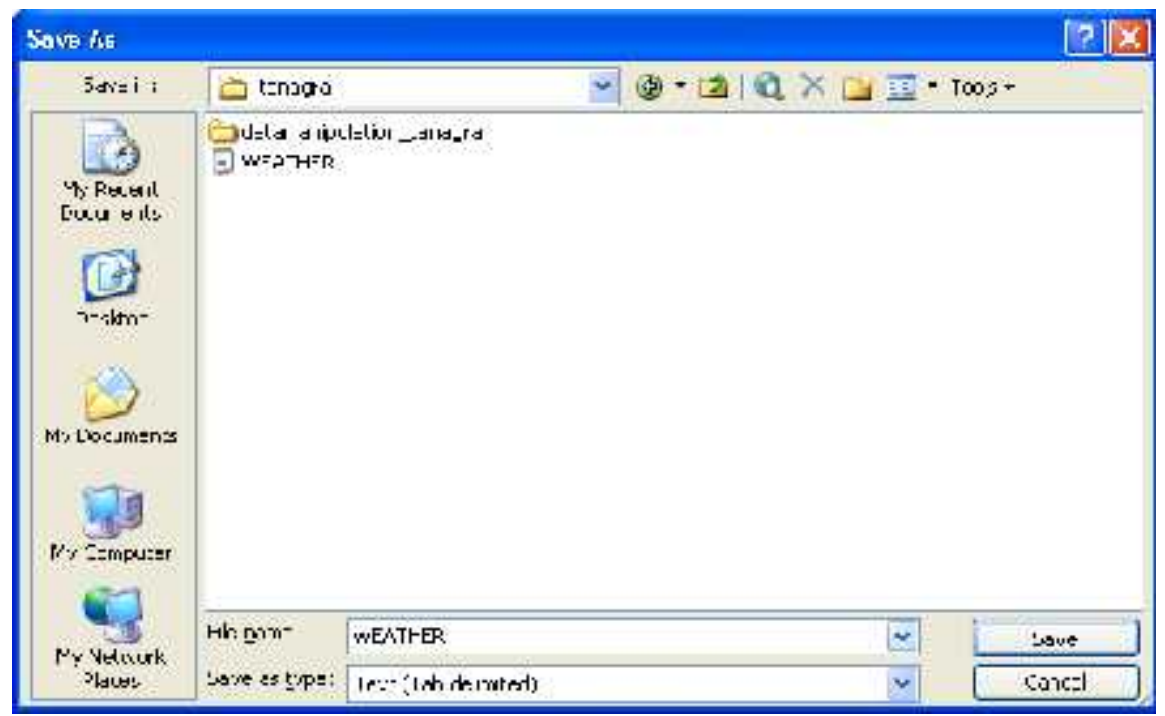

Gambar 2. Penyimpanan File Text 


\section{Penggunaan Tanagra}

\section{Meng-Import Data dari Text File Excel}

Setelah file data set dibentuk dalam format text Excel, untuk selanjutnya proses penambangan data dapat dilakukan menggunakan software Tanagra. Untuk itu software Tanagra di aktifkan sehingga User Interface Tanagra seperti gambar 3 ditampilkan

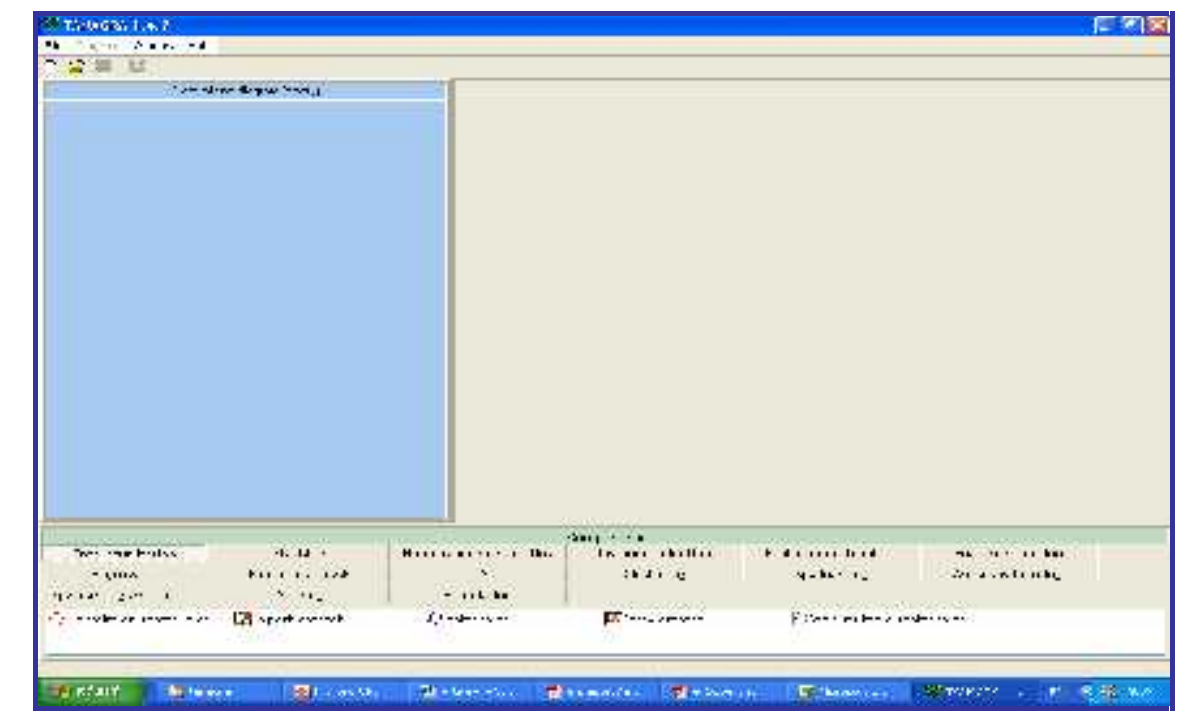

Gambar 3. User Interface TANAGRA

Pada bagian bawah UI Tanagra disediakan komponen-komponen yang dapat digunakan untuk melakukan proses penambangan data, sebagian diantaranya akan dijelaskan pada tulisan ini.

Untuk meng-import data set text Excel buka lembaran baru diagram data mining dengan meng-klik menu
File/New pada menu utama selanjutnya dialog box pemilihan dataset seperti gambar 4 akan ditampilkan. Ada 3 (tiga) informasi yang harus diisikan kedalam dialig box ini yaitu: Diagram Title, Data mining diagram file name dan Dataset. Dalam gambar 4 diberikan contoh pengisian informasi ini.

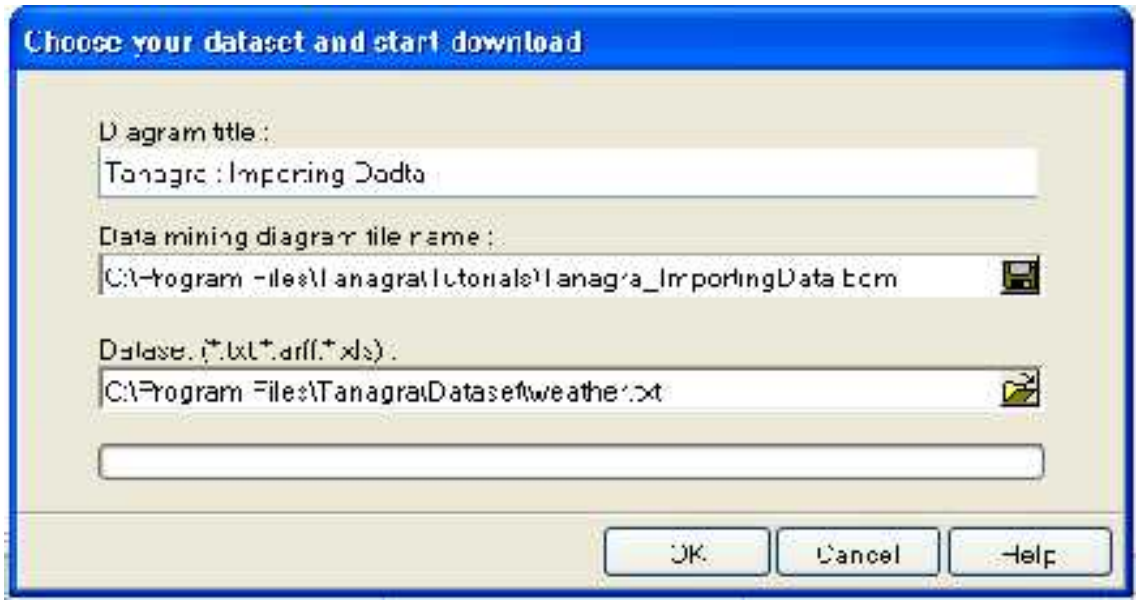

Gambar 4. Setting Dokumen 
Setelah setting selesai, tekan OK untuk memastikan setting yang dibuat dan selanjutnya pada User Interface Tanagra ditampilkan sebuah diagram data mining baru berdasarkan pada file < weather.txt >. Pada bagian kanan User Interface tanagra diperlihatkan informasi tentang download file yang dilakukan dan data set description, seperti gambar 5. Ketika meng-create diagram baru, disini kita menggunakan extension
(.BDM) untuk nama file diagram ( tanagra_ImportingData.BDM >). BDM (Binary Diagram) adalah extension untuk file Tanagra yang mengandung deskripsi diagram, juga data set yang di import (dalam hal ini data dari file < weather.txt >). Dengan demikian kita akan kehilangan asosiasi (hubungan) ke filetext data set. Modifikasi ataupun penghapusan data filetext data set tidak mempengaruhi kerja dalam Tanagra.

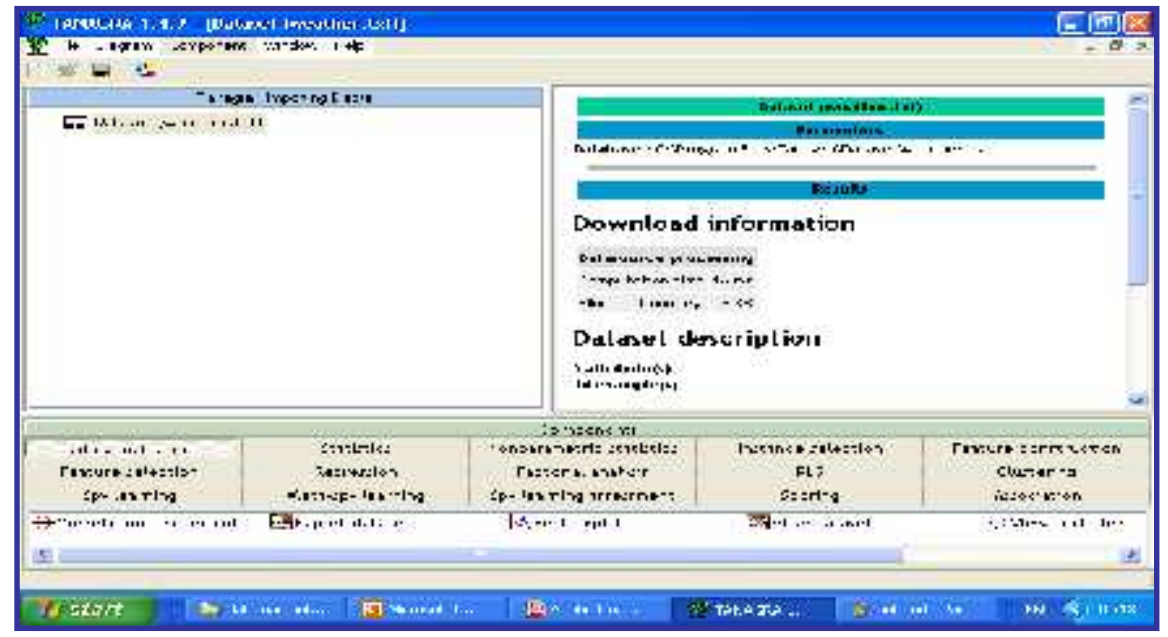

Gambar 5. Diagram yang di create berdasarkan file weather.txt

Format file diagram Tanagra lainnya adalah dengan extension TDM (Text Diagram). Dengan TDM, selain menyimpan deskripsi diagram kita hanya menyimpan refrensi file data set. Sehingga jika dilakukan perubahan pada file data set (〈weather.txt 〉) akan terjadi perubahan hasil saat dilakukan eksekusi pada urutan operasi Tanagra berikutnya. Jadi jangan menghapus file data asal jika ingin membuka kembali file diagram Tanagra, karena akan diperoleh hasil yang berbeda.

\section{Pengolahan untuk Basic Statistic}

Pada bagian ini akan dicontohkan karakteristik dasar dari User Interface Tanagra melalui analisis file data set breast.txt. Data set ini berasal dari medical domain yang terdiri dari karakteristik sel yang disampel dari sel yang mengandung tumor ganas atau tidak. Contoh ini menjelaskan penggunaan dari beberapa komponen seperti pada table 1. Bagian data yang dioleh dengan Tanagra diperlihatkan pada tabel 2 . 
Tabel 1. Komponen yang digunakan

\begin{tabular}{|l|l|l|}
\hline Tab & Operator (Component) & Function \\
\hline Data visualization & View dataset & Memperlihatkan isi data file dalag grid \\
\hline Feature selection & Define status & Spesifikasi penggunaan atribut \\
\hline Descriptive statistic & $\begin{array}{l}\text { Univariate continuous } \\
\text { statistic }\end{array}$ & $\begin{array}{l}\text { Descriptive statistic untuk continuous } \\
\text { attribute }\end{array}$ \\
\hline Descriptive statistic & $\begin{array}{l}\text { Univariate discrete } \\
\text { statistic }\end{array}$ & $\begin{array}{l}\text { Descriptive statistic untuk discrete } \\
\text { attribute }\end{array}$ \\
\hline Descriptive statistic & Group characterization & Statistik untuk sub-populasi \\
\hline
\end{tabular}

Tabel 2. Data dari file breast.txt

\begin{tabular}{|c|c|c|c|c|c|c|c|c|c|}
\hline Cellshape & \multicolumn{2}{|c|}{ ucellsize } & \multicolumn{2}{|c|}{ ucellshape } & \multicolumn{2}{c|}{ mgadhesion } & sepics & bnuclei & bchromatin \\
\hline 4 & 2 & 2 & 1 & 2 & 1 & 2 & 1 & 1 & begnin \\
1 & 1 & 1 & 1 & 2 & 1 & 2 & 1 & 1 & begnin \\
2 & 1 & 1 & 1 & 2 & 1 & 2 & 1 & 1 & malignant \\
10 & 6 & 6 & 2 & 4 & 10 & 9 & 7 & 1 & begnin \\
4 & 1 & 1 & 1 & 2 & 1 & 2 & 1 & 1 & begnin \\
1 & 1 & 1 & 1 & 2 & 1 & 1 & 1 & 1 & begnin \\
1 & 1 & 1 & 1 & 2 & 1 & 2 & 1 & 1 & begnin \\
5 & 1 & 1 & 1 & 2 & 1 & 2 & 1 & 1 & begnin \\
3 & 1 & 1 & 1 & 2 & 1 & 2 & 1 & 1 & begnin \\
1 & 1 & 1 & 1 & 2 & 4 & 2 & 1 & 1 & begnin \\
5 & 3 & 3 & 2 & 3 & 1 & 3 & 1 & 1 & begnin \\
4 & 2 & 2 & 1 & 2 & 1 & 2 & 1 & 1 & begnin \\
1 & 1 & 1 & 1 & 2 & 1 & 2 & 1 & 1 & begnin \\
. &. &. &. &. &. &. &. &. &. \\
. &. &. &. &. &. &. &. &. &. \\
. &. &. &. &. &. &. &. &. &. \\
\hline
\end{tabular}

Dan seterusnya ada sebanyak 699 sampel data

Analisis ini diawali dengan meng-import file data dengan cara seperti yang telah dijelaskan pada bagian diatas dengan setting document seperti diperlihatkan pada gambar 5, dilanjutkan dengan menekan tombol $\mathrm{OK}$ untuk penetapan. 


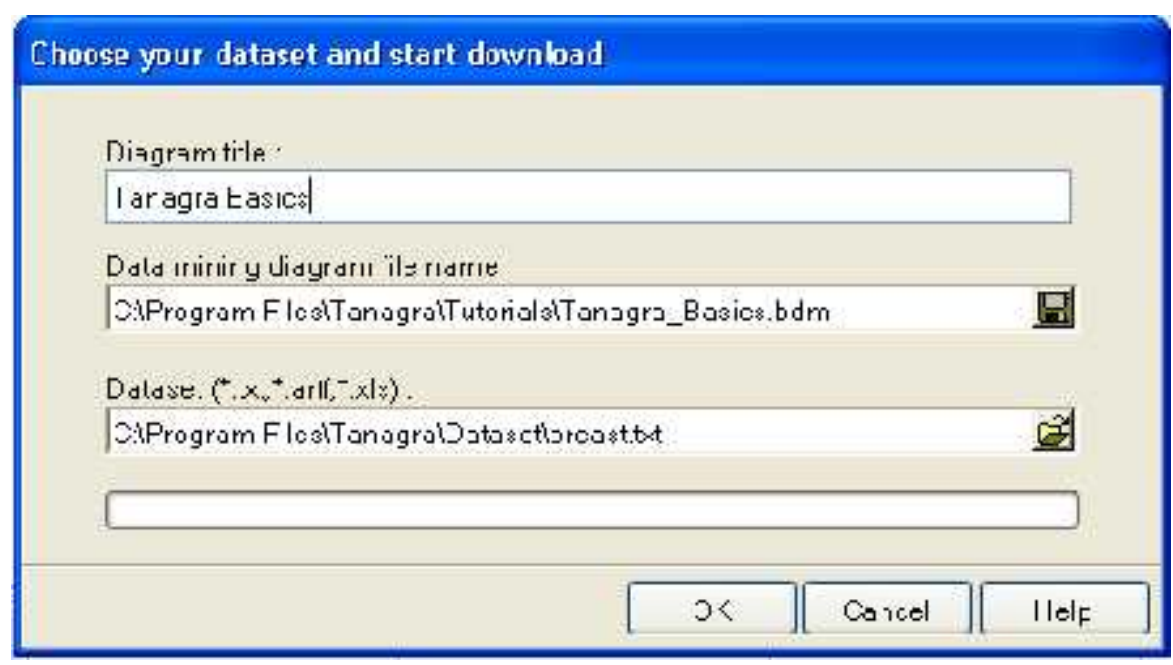

Gambar 6. Setting dokumen untuk analisis file breast.txt

Selanjutnya dimulai melakukan analisis, dengan tahapan sebagai berikut:

- Tambahkan komponen View Dataset (pada component palette "DATA VISUALIZATION", ke diagram dibawah node Dataset(Breast.txt).

- Klik View Dataset node untuk memilihnya, selanjutnya klik kanan View Dataset tersebut untuk menampilkan popup menu: pilih View command, data akan ditampilkan dibagian kanan frame, seperti pada gambar 6 .

Dalam Tanagra dapat dibangun daftar urutan operasi, namun hampir semua operator memerlukan pen-definisian kegunaan atribut dan bagaimana pengguaannya sebelum dieksekusi. Komponen Define status ada didalam component palette FEATURE SELECTION tab. Langkah pendefinisian adalah sebagai berikut:

- Tempatkan komponen Define status dibawah node Dataset(Breast.txt), click kanan, pilih parameter ...Command.

- Didalam dialog box terlihat sejumlah pilihan continuous variables, klik pilihan yang disebelah kiri kemudian klik tombol panah. List yang diklik akan berfungsi sebagai input, karena tab input sedang aktif (gambar 6). Klik OK 


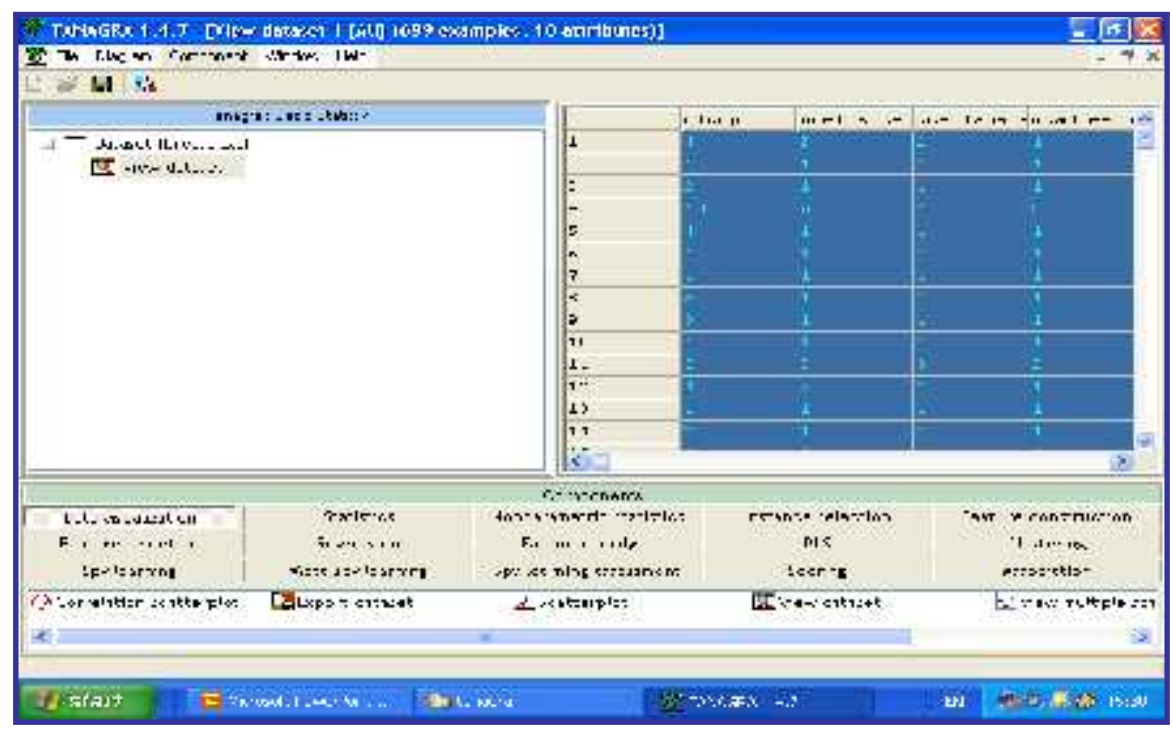

Gambar 7. Tampilan data yang diimport dari file breast.txt

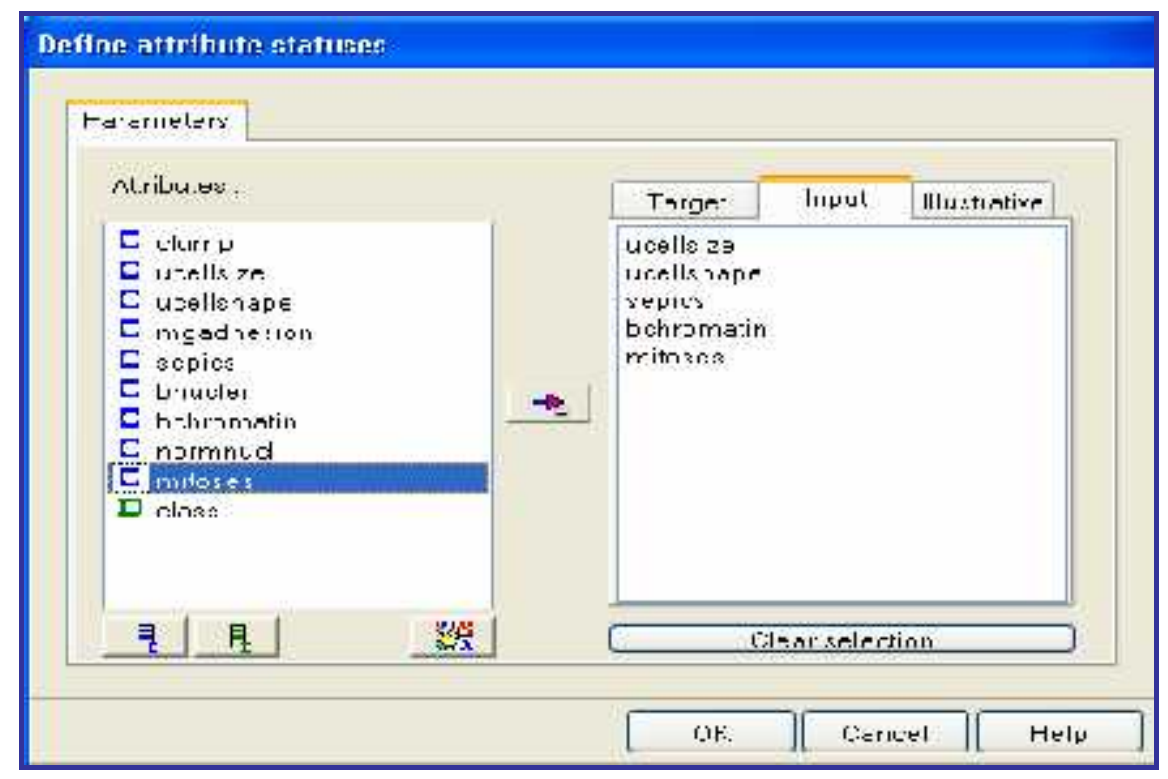

Gambar 8. Dialog box penetapan parameter

- Tambahkan komponen Univariate continuous statistic (DESCRIPTIVE STATISTIC tab) ke diagram dibawah Define status 1. Pada popup menu pilih View command. Descriptive statistic untuk atribut yang dipilih akan ditampilkan di frame kanan seperti pada gambar 8 . 


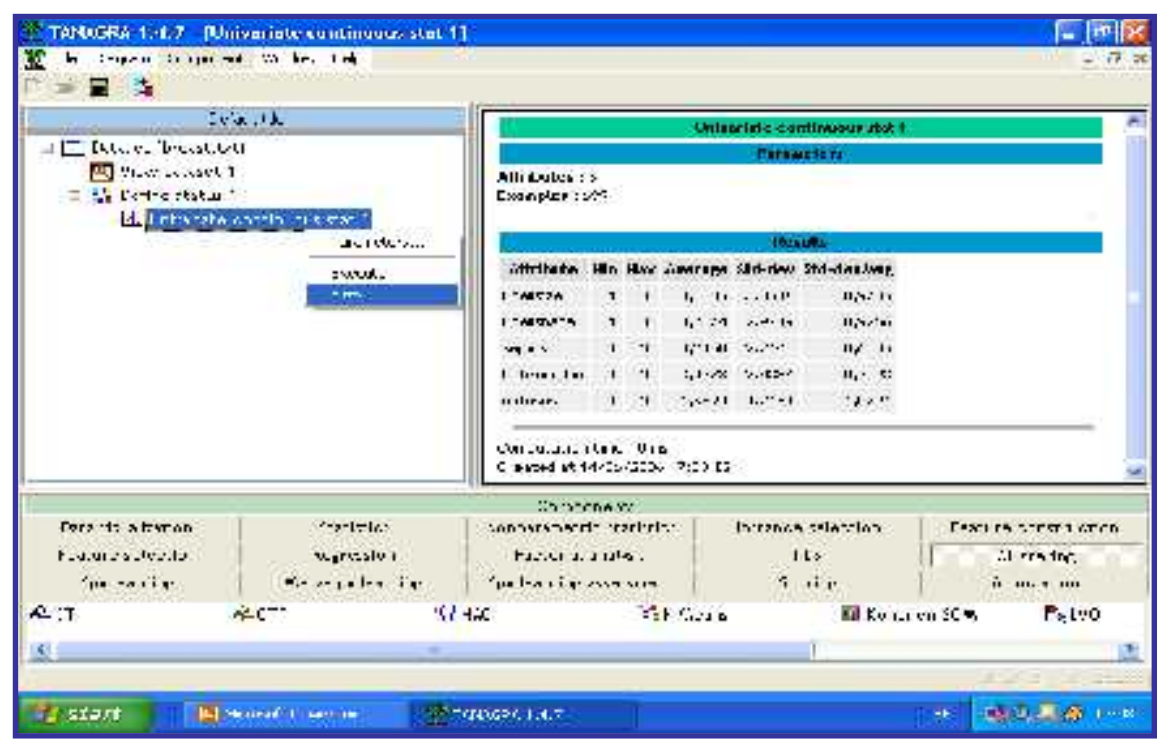

\section{Gambar 9. Hasil Univariate Continuous Statistic}

- Tambahkan Define status 2, seperti sebelumnya. Pilih discrete attribute (class). Tambahkan Univariate discrete statistic kebawah define status 2. Pilih View command seperti sebelumnya. Hasilnya seperti gambar
9. Diperlihatkan jumlah dan persentase sampel yang menderita tumor jinak (begnin) atau ganas (malignant) sebesar 458 dan 241 orang $(65,52 \%$ dan $34,48 \%)$.

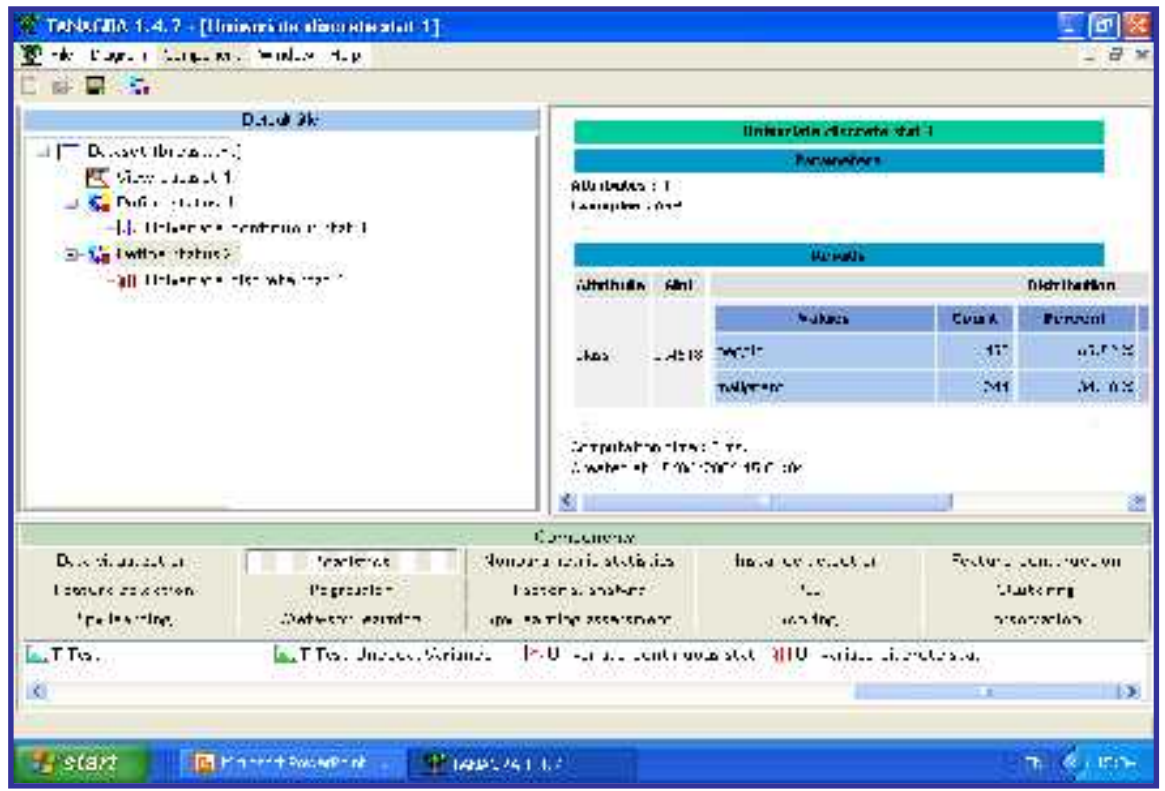

Gambar 10. Hasil Univariate Discrete Statistic

Untuk statistic sub-populasi (karakteristik wanita mengandung tumor ganas atau tidak), tambahkan define status 3 seperti sebelumnya.
Tempatkan Group characterization kebawahnya. Pilih View pada popup menu. Hasilnya seperti gambar 9. 


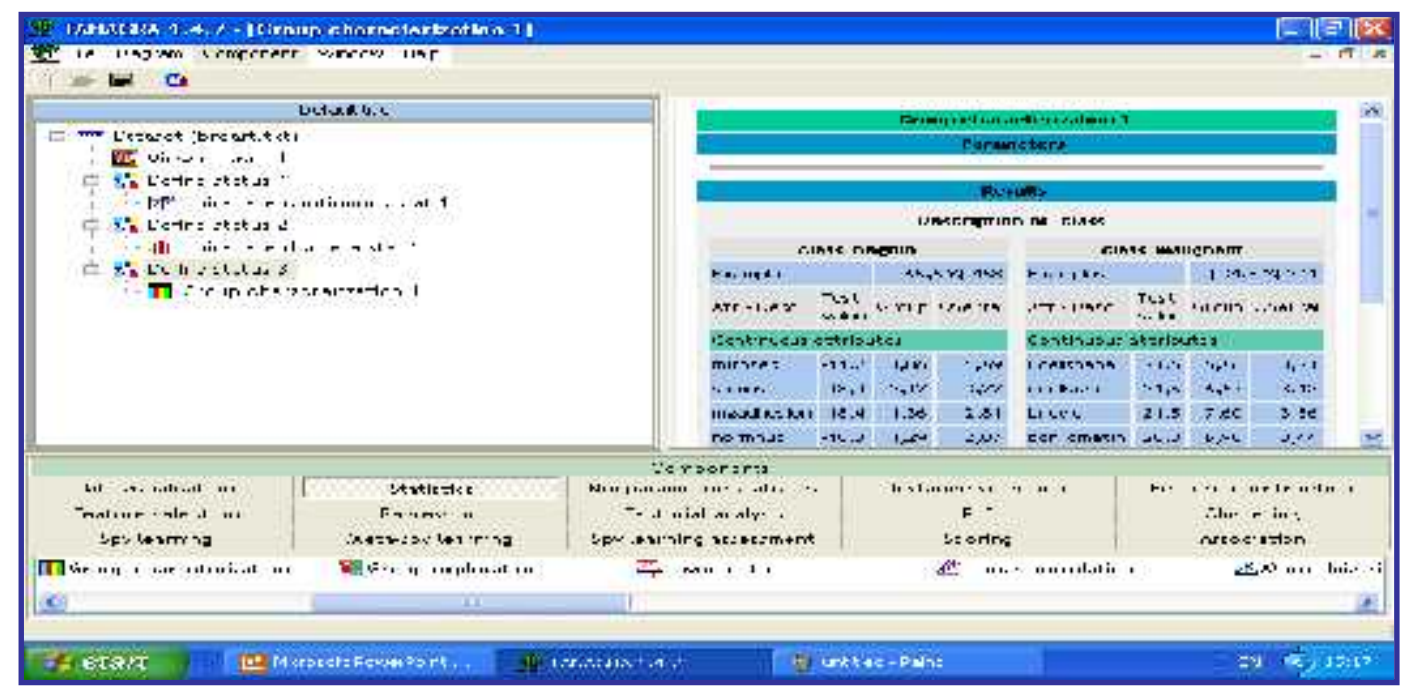

Gambar 9. Hasil Group Characterization Hasil ini memperlihatkan bahwa rata-rata wanita dengan tumor jinak (begnin) mempersembahkan nilai mitoses yang lebih kecil (1,6 : 1,59 untuk populasi lengkap). Disisi lain, nilai ucellshape attribute masih pada rata-rata, lebih tinggi untuk wanita dengan tumor ganas $(6,56: 3,21)$.

\section{KESIMPULAN}

Dari uraian yang diberikan diatas dapat diambil kesimpulan sebagai berikut :

1. Tanagra merupakan software data mining yang dapat mengolah data

2. Contoh aplikasi Tanagra ini menggunakan data pasien yang tidak diperlihatkan informasiinformasi yang dapat diperoleh.

3. Univariate Continuous Statistic menunjukkan hasil begnin $65,52 \%$ dan malignant $34,48 \%$

4. Informasi lain yang diperoleh adalah karakteristik grup dari penderita tumor jinak memberikan nilai motosis yang lebih kecil $(1,6: 1,59)$, serta nilai ucellshape tumor ganas lebih tinggi $(6,56: 3,21)$

\section{Saran}

1. Untuk selanjutnya data yang digunakan dapat disesuaikan dengan kebutuhan peneliti.

2. Data yang ditambang merupakan data-data dalam jumlah yang besar. dalam format text yang dibentuk dengan Excel. mengandung penyakit tumor ganas atau

\section{Daftar Pustaka}

1. http://en.wikipedia.org/wiki/ tanagra, Tanagra

2. _http://eric.univ-Iyon2.fr/-ricco /tanagra/en/tanagra.html, Tanagra, $\mathrm{T}$ utorial Data Manipulation

3._ http://data-mining-tutorials. blogspot.com/Tangra-Data Mining Tutorials

4. _ http://eric.univ-Iyon2.fr/$\underline{\text { ricco/tanagra/fichiers/enBasics.pdf. }}$ $\underline{\text { Tutorial overview }}$ 
ISSN: 2085-6989 
ISSN: 2085-6989 